\title{
clpB, a class III heat-shock gene regulated by CtsR,
is involved in thermotolerance and virulence of
Enterococcus faecalis \\ Correspondence \\ Marcia Giambiagi-deMarval marciagm@micro.ufr.j.br \\ Received 3 June 2010 \\ Revised 24 November 2010 \\ Accepted 6 December 2010

\author{
Naira Elane Moreira de Oliveira, ${ }^{1,2}$ Jaqueline Abranches, ${ }^{2}$ \\ Anthony O. Gaca, ${ }^{2}$ Marinella Silva Laport, ${ }^{1}$ Clarissa R. Damaso, ${ }^{3}$ \\ Maria do Carmo de Freire Bastos, ${ }^{1}$ José A. Lemos ${ }^{2}$ \\ and Marcia Giambiagi-deMarval ${ }^{1}$ \\ ${ }^{1}$ Instituto de Microbiologia Paulo de Góes, Bloco I, Universidade Federal do Rio de Janeiro, CCS, \\ Cidade Universitária, 21491-902, Rio de Janeiro, RJ, Brazil \\ ${ }^{2}$ Center for Oral Biology, Department of Microbiology and Immunology, University of Rochester \\ Medical Center, Rochester, NY 14642, USA \\ ${ }^{3}$ Instituto de Biofísica Carlos Chagas Filho, Bloco G, Universidade Federal do Rio de Janeiro, CCS, \\ Cidade Universitária, 21491-902, Rio de Janeiro, RJ, Brazil
}

\begin{abstract}
Here, we transcriptionally and phenotypically characterized the $c / p B$ gene from Enterococcus faecalis. Northern blot analysis identified a monocistronic mRNA strongly induced at 48 and $50{ }^{\circ} \mathrm{C}$. In silico analysis identified that the $c / p B$ gene encodes a protein of 868 aa with a predicted molecular mass of approximately $98 \mathrm{kDa}$, presenting two conserved ATP-binding domains. Sequence analysis also identified a CtsR-binding box upstream of the putative -10 sequence, and inactivation of the $c t s R$ gene resulted in an approximately 2-log increase in $c / p B$ mRNA expression, confirming ClpB as a member of the CtsR regulon. While expression of $c / p B$ was induced by heat stress, a $\Delta c / p B$ strain grew relatively well under many different stressful conditions, including elevated temperatures. However, expression of ClpB appears to play a major role in induced thermotolerance and in pathogenesis, as assessed by using the Galleria mellonella virulence model.
\end{abstract}

\section{INTRODUCTION}

Enterococcus faecalis inhabits the gastrointestinal tract of humans and animals and can also colonize the oral cavity, genito-urinary tract and skin. This bacterium is also an important opportunistic pathogen, particularly as an aetiological agent of nosocomial infections accounting for approximately $12 \%$ of the hospital-acquired infections in the USA (Murray, 1990; Fisher \& Phillips, 2009). E. faecalis can cause a variety of diseases including bacteraemia, endocarditis, intra-abdominal, urinary tract and soft tissue infections (Murray, 1990). The strong association of this organism with infections in hospital settings has been attributed to its inherent capacity to withstand harsh environmental conditions, and to its innate and acquired resistance to multiple antibiotics. The ability of E. faecalis to survive under adverse conditions is particularly important, and many of its stress-resistant characteristics have been used to distinguish enterococci from other Gram-positive cocci (Murray, 1990). For example, E.

Abbreviation: qRT-PCR, quantitative real-time reverse-transcriptase PCR. faecalis can grow at temperatures ranging from 5 to $50{ }^{\circ} \mathrm{C}$ and in a wide $\mathrm{pH}$ range (4.6-9.9), and can tolerate and grow in the presence of $6.5 \% \mathrm{NaCl}$ or $40 \%$ bile salts (Murray, 1990).

The stress responses of $E$. faecalis have been the subject of extensive research. It has been demonstrated that preexposure to sublethal stresses, oligotrophic conditions or glucose starvation leads to an overall increase in stress resistance (Flahaut et al., 1996a, b, 1997; Giard et al., 1997; Hartke et al., 1998). A correlation has been made between the capacity to adapt to stress and the cross-protection phenomenon with the increased synthesis of many proteins, but, with a few exceptions such as the general stress protein Gls24 and the molecular chaperones GroEL and DnaK, the identity of the majority of these proteins remains unknown (Flahaut et al., 1996a, b, 1997; Hartke et al., 1998; Giard et al., 2000; Laport et al., 2004, 2006). In many bacteria, Clp ATPases and ClpP proteolytic complexes are protein machines that play crucial roles in promoting folding, assembly or degradation of proteins during normal growth and, in particular, under stressinducing conditions (Houry, 2001; Frees et al., 2004). Two 
classes of Clp ATPases have been identified based on the presence of one or two ATP-binding domains and the occurrence of specific signature sequences (Wawrzynow et al., 1996). Class 1 consists of relatively large proteins, such as ClpA, ClpB, ClpC, ClpE and ClpL, with two distinct ATP-binding domains, whereas class 2 proteins, such as ClpX and ClpY, display a single ATP-binding domain (Schirmer et al., 1996). In low-GC Gram-positive bacteria, transcription of $c l p P$ and selected clp ATPase genes is negatively regulated by CtsR (for class three stress repressor), which recognizes a repeated heptanucleotide (A/GGTCAAANANA/GGTCAA) that usually overlaps with the transcription initiation site or the -35 and -10 sequences of the promoter of the corresponding gene (Derré et al., 1999). In addition to repression by CtsR, additional mechanisms involved in control of clp expression have been identified in low-GC Gram-positive bacteria, including dual repression of $c l p P$ by CtsR and HrcA in Streptococcus salivarius (Chastanet \& Msadek, 2003).

Given the variety of environmental stresses that E. faecalis withstands, it is likely that the Clp proteins may play a role in stress survival and virulence. The genome of E. faecalis encodes a homologue of the gene encoding the $\mathrm{ClpP}$ peptidase, three orthologues of class 1 Clp ATPases (ClpB, $\mathrm{ClpC}$ and $\mathrm{ClpE}$ ), and one class 2 Clp ATPase (ClpX) (Paulsen et al., 2003). Among the class 1 Clp ATPases found in E. faecalis, ClpB is distinguished from the other large Clp ATPases by a relatively longer spacer region between the two ATP-binding domains (Houry, 2001), and by the absence of the ClpP recognition tripeptide. In Escherichia coli, ClpB has been shown to act synergistically with the DnaK system to remodel or dissolve protein aggregates that arise from heat stress (Doyle et al., 2007), but it is not known whether ClpB-DnaK interactions also occur in Gram-positive bacteria. In both Gram-positive and Gram-negative bacteria, inactivation of $c l p B$ normally results in reduced thermotolerance (Chastanet et al., 2004; Frees et al., 2004; Yuan et al., 2007). ClpB has also been associated with multiplication or survival of Staphylococcus aureus and Porphyromonas gingivalis within mammalian cells (Frees et al., 2004; Capestany et al., 2008). Moreover, animal models have been used to demonstrate that ClpB is important for virulence of bacterial pathogens, including Listeria monocytogenes and P. gingivalis (Chastanet et al., 2004; Yuan et al., 2007).

In this study, we report the genetic and physiological characterization of the $c l p B$ gene in E. faecalis. Transcriptional analysis revealed that $\operatorname{clp} B$ expression is induced by a variety of stress conditions and negatively regulated by CtsR. Although inactivation of $c l p B$ had no major impact on the ability of E. faecalis to grow under different stress conditions, induced thermotolerance and virulence in the Galleria mellonella insect model were significantly reduced in the absence of ClpB.

\section{METHODS}

Bacterial strains and general culture conditions. Bacterial strains used in this study are listed in Table 1. Escherichia coli strains were routinely grown in Luria-Bertani medium and used for plasmid construction and propagation. E. faecalis strains and its derivatives were grown in brain heart infusion (BHI) medium at $37^{\circ} \mathrm{C}$. When required for selective growth of strains, erythromycin $\left(10 \mu \mathrm{g} \mathrm{ml}^{-1}\right.$ for E. faecalis, $300 \mu \mathrm{g} \mathrm{ml}^{-1}$ for Escherichia coli), spectinomycin $(1000 \mu \mathrm{g}$ $\left.\mathrm{ml}^{-1}\right)$, rifampicin $\left(200 \mu \mathrm{g} \mathrm{ml}^{-1}\right)$ or fusidic acid $\left(25 \mu \mathrm{g} \mathrm{ml}^{-1}\right)$ was added to the growth medium.

Construction of $E$. faecalis $\Delta c / p B$ or $\Delta c t s R$ strains. A markerless genetic exchange system was used for construction of the $\operatorname{clp} B$ and ctsR deletion mutants in E. faecalis OG1RF (Kristich et al., 2007). To create each strain, two PCR fragments (each approximately $1 \mathrm{~kb}$ in size) flanking the target gene were obtained with the primers listed in Table 2. After digestion with the appropriate restriction enzymes, the two PCR products flanking the gene of interest were simultaneously cloned into pGEM7 (Promega) to give plasmids pGclpB and pGctsR in Escherichia. coli $\mathrm{DH} 10 \mathrm{~B}$. The $2 \mathrm{~kb}$ fragments containing the $\operatorname{clp} B$ (pGclpB) and $c t s R$ (pGctsR) up-down fragments were subcloned into pCJK47 using Escherichia coli EC1000 as the host strain. The resulting plasmids, $\mathrm{pCJK}-c l p B$ and $\mathrm{pCJK}-c t s R$, were electroporated into competent E. faecalis CK111 (donor strain). The E. faecalis CK111 strains containing the $\mathrm{pCJK}-c l p B$ and $\mathrm{pCJK}-c t s R$ plasmids were conjugated with wild-type $E$. faecalis OG1RF and transformants were selected on BHI agar medium containing rifampicin and erythromycin. Single colonies were subjected to the $\mathrm{PheS}^{\star}$ negative counter-selection

Table 1. Bacterial strains used in this study

Fus, Fusidic acid; Rif, rifampicin; Sp, spectinomycin.

\begin{tabular}{|c|c|c|}
\hline Strains & Relevant characteristic & Source \\
\hline \multicolumn{3}{|c|}{ E. faecalis } \\
\hline OG1RF & Laboratory strain; Rif $^{r}$ Fus $^{r}$ & Lab stock \\
\hline $\mathrm{EF}-c l p B$ & $c l p B$ deletion mutant of OG1RF, $\Delta c l p B$ & This study \\
\hline $\mathrm{EF}-\mathrm{cts} R$ & ctsR deletion mutant of OG1RF, $\Delta c t s R$ & This study \\
\hline$c \Delta c l p B$ & EF-clpB harbouring pTG55 (pMSP3535 expressing $c l p B$ ) & This study \\
\hline DH10B & Cloning host & Grant et al. (1990) \\
\hline EC1000 & Host for cloning RepA-dependent plasmids & Leenhouts et al. (1996) \\
\hline
\end{tabular}


Table 2. Oligonucleotide primers and probes used in this study

The underlined bases correspond to restriction sites included to aid in the subsequent cloning of the PCR products.

\begin{tabular}{|c|c|c|}
\hline Primer name & Sequence $\left(5^{\prime}-3^{\prime}\right)$ & Application \\
\hline FW $c l p B$ UP & GGAGGATGG AATTCTCGCTTTTCT & $c l p B$ deletion \\
\hline $\mathrm{RV} \operatorname{clp} B \mathrm{UP}$ & TGAGCTTCACCCGGGGCCTCTTGA & $c l p B$ deletion \\
\hline $\mathrm{RV} \operatorname{clp} B$ DOWN & AACCCTTGGGCATGCGACAGACAA & $c l p B$ deletion \\
\hline FW $c t s R$ UP & CTTTGCAAAAGGATCCGCG & cts $R$ deletion \\
\hline $\mathrm{RV} c t s R$ UP & AGCCTCAAGAATTCCTGACGTATT & $c t s R$ deletion \\
\hline RV $c t s R$ DOWN & CCAACTACTGGATCCAAAC & $c t s R$ deletion \\
\hline $\operatorname{clp} B$ forw 3 & CAAAGGATCCAAGAGTTGGTCAAAC & $\Delta c l p B$ complementation \\
\hline $\operatorname{clp} B$ rev 3 & GAATTCCGTCTCGAGTTACACTTC & $\Delta c l p B$ complementation \\
\hline $\operatorname{clp} B$ forw 2 & GATGCTGGTTTAGATGTTGACG & qRT-PCR \\
\hline $\operatorname{clp} B$ rev 2 & CGAAGTGAATCAGCTTCTTGC & qRT-PCR \\
\hline 16S RNA-F & CGCTAGTAATCGTGGATCAGAATG & qRT-PCR \\
\hline
\end{tabular}

system to isolate double crossover deletions as described elsewhere (Kristich et al., 2007). The $c l p B$ and $c t s R$ gene deletions were confirmed by PCR sequencing of the insertion site and flanking sequences.

Construction of complemented $\mathbf{c l p B}$ strain. To express the $\operatorname{clp} B$ gene in trans, the full-length $\operatorname{clp} B$ gene including the ribosomebinding site was amplified by PCR with primers containing BamHI restriction sites (Table 2) and ligated into pMSP3535 (Bryan et al., 2000), which had been digested with BamHI and XhoI. The ligation mixture containing the pMSP3535 expressing $c l p B$ was electroporated onto CK111 and subsequently conjugated with E. faecalis $\Delta c l p B$. The resulting plasmid (pTG55) contains the intact $\operatorname{clp} B$ gene under the control of the lactococcal nisin promoter. Expression of $c l p B$ from pTG55 was induced by adding $5 \mathrm{ng}$ nisin $\mathrm{ml}^{-1}$ to exponentially grown cultures.

Stress challenges. To investigate the role of the E. faecalis $\mathrm{ClpB}$ in stress responses, cells of the wild-type OG1RF and its isogenic $c l p B$ mutant were subjected to a variety of stress challenges. For Northern blot analysis, cells were grown in BHI to mid-exponential phase $\left(\mathrm{OD}_{600} \sim 0.5\right)$ and subjected to heat shock at $42,45,48$ or $50{ }^{\circ} \mathrm{C}$. To evaluate the capacity of $E$. faecalis strains to grow under stress conditions $\left(5 \% \mathrm{NaCl}, \mathrm{pH} 5, \mathrm{pH} 9\right.$ and $\left.2 \mathrm{mM} \mathrm{H}_{2} \mathrm{O}_{2}\right)$, midexponential phase cultures grown in BHI were diluted $1: 100$ into fresh BHI medium adjusted to each specific condition and growth was monitored using a Bioscreen $\mathrm{C}$ growth monitor (Oy Growth Curves $\mathrm{Ab}$ ). Disc inhibition assays were used to assess the sensitivity of the strains to $\mathrm{H}_{2} \mathrm{O}_{2}, \mathrm{HCl}$ or $\mathrm{NaOCl}$. Briefly, a uniform layer of exponentially grown cells was spread onto $\mathrm{BHI}$ agar plates using a sterile swab, and filter paper discs ( $1 \mathrm{~mm}$ diameter) saturated with each solution $\left(5 \% \mathrm{H}_{2} \mathrm{O}_{2}, 3 \mathrm{M} \mathrm{HCl}\right.$ or $\left.10 \% \mathrm{NaOCl}\right)$ were placed onto the agar. All plates were incubated at $37{ }^{\circ} \mathrm{C}$ for $48 \mathrm{~h}$ after which the halo of inhibition was recorded. To test the involvement of ClpB in induced thermotolerance, cultures were grown in BHI or BHI containing erythromycin for the complemented mutant. Briefly, cultures were grown exponentially at $37{ }^{\circ} \mathrm{C}$ to an $\mathrm{OD}_{600} \sim 0.4$ and split in two aliquots; one aliquot remained at $37^{\circ} \mathrm{C}$ while the other was incubated at the sublethal temperature of $50{ }^{\circ} \mathrm{C}$. After $30 \mathrm{~min}$ incubation at 37 or $50{ }^{\circ} \mathrm{C}$, both cultures were incubated at a lethal temperature of $60{ }^{\circ} \mathrm{C}$ for 30 and $60 \mathrm{~min}$. ClpB expression in the complemented $\Delta c l p B$ strain $(c \Delta c l p B)$ was induced by adding nisin
(5 $\mathrm{ng} \mathrm{ml}^{-1}$ ) to exponentially grown cultures $\left(\mathrm{OD}_{600} \sim 0.1\right)$. Cell survival was evaluated by plating serially diluted aliquots on BHI plates that were incubated at $37{ }^{\circ} \mathrm{C}$ for $48 \mathrm{~h}$ prior to counting c.f.u. The capacity of the $\triangle c l p B$ mutant to tolerate oxidative stress was further investigated in an $\mathrm{H}_{2} \mathrm{O}_{2}$ killing assay. Briefly, exponentially grown cultures were incubated at $37^{\circ} \mathrm{C}$ in the presence of $30 \mathrm{mM}$ $\mathrm{H}_{2} \mathrm{O}_{2}$. Every $30 \mathrm{~min}$ for up to $2 \mathrm{~h}$, aliquots were taken and serially diluted, plated on BHI plates and incubated at $37{ }^{\circ} \mathrm{C}$ for $48 \mathrm{~h}$ before colonies were counted.

Biofilm assay. Biofilm formation on polystyrene microtitre plates was quantified essentially as described previously (Loo et al., 2000). Briefly, biofilms were grown in a semi-defined biofilm medium (BM) containing glucose as the carbohydrate source for $24 \mathrm{~h}$ at $37^{\circ} \mathrm{C}$ before adherent bacteria were stained with $0.1 \%$ crystal violet. The bound dye was extracted from the stained cells with $33 \%$ acetic acid solution, and the biofilms were quantified by measuring $\mathrm{OD}_{575}$.

Metabolic labelling of proteins and Western blotting. Overnight cultures were diluted in BHI to $10^{7}$ c.f.u. $\mathrm{ml}^{-1}$ and incubated for $30 \mathrm{~min}$ at $37^{\circ} \mathrm{C}$. For continuous labelling at different temperatures, cells were concentrated by centrifugation to $10^{8}$ c.f.u. $\mathrm{ml}^{-1}$ in a methionine-free essential medium (MEM; Difco) containing $200 \mu \mathrm{Ci}$ $\left.\mathrm{ml}^{-1}\left(7.4 \mathrm{MBq} \mathrm{ml}{ }^{-1}\right){ }^{32} \mathrm{~S}\right] \mathrm{methionine.} \mathrm{Control} \mathrm{cells} \mathrm{were} \mathrm{labelled} \mathrm{at}$ $37^{\circ} \mathrm{C}$, whereas heat-shocked cells were labelled at $42,45,48,50$ or $52{ }^{\circ} \mathrm{C}$. After $30 \mathrm{~min}$ incubation at the different temperatures, protein lysates from each set of samples obtained by lysozyme treatment were separated by $7.5 \%$ SDS-PAGE. After separation, the gel was stained with Coomassie blue, destained, dried and exposed to an X-ray film for detection of radiolabelled proteins. Alternatively, a duplicate gel was transferred to a nitrocellulose membrane for Western blot analysis using a polyclonal antibody raised against the Synechococcus spp. ClpB (a generous gift from Dr Adrian K. Clarke) (Eriksson \& Clarke, 1996). Immune reactivity was visualized using the Western blotting luminol reagent according to the manufacturer's recommendations (Santa Cruz Biotechnology).

RNA methods. For each growth condition, cell pellets were collected by centrifugation and immediately treated with the RNA protect reagent (Qiagen). Total RNA was isolated by the hot acid-phenol method as described previously (Abranches et al., 2006). The crude 
RNA was treated with DNase I (Ambion) and then further purified by using the RNeasy mini kit (Qiagen), including an on-column DNase I digestion (Qiagen). For Northern analysis, RNA was separated on a $1.2 \%$ agarose-formaldehyde denaturing gel and blotted to a nitrocellulose membrane as described elsewhere (Sambrook \& Russell, 2001). The membrane was probed with a fragment of the E. faecalis $c l p B$ gene labelled with $\left[\alpha_{-}^{32} \mathrm{P}\right] \mathrm{dCTP}$ and the ready-to-go DNA labelling beads system according to the manufacturer's recommendations (Amersham Pharmacia Biotech). To confirm the integrity and the amount of RNA analysed in the Northern blot, a replica gel was stained with ethidium bromide. For quantitative realtime reverse-transcriptase PCR (qRT-PCR) analysis, cDNA was generated from three independent RNA samples using the SuperScript first-strand synthesis system kit (Invitrogen) and genespecific primers. The primers used for qRT-PCR were designed using the Beacon designer 2.0 software (Premier Biosoft International). qRT-PCR was carried out by following the protocols described elsewhere (Ahn et al., 2005). A Student's $t$ test was performed to verify significance of the qRT-PCR results.

Galleria mellonella infection. For the G. mellonella killing assays, insects in the final larval stage were purchased from Vanderhorst Inc., stored at $4{ }^{\circ} \mathrm{C}$ in the dark and used within 5 days of shipment. Groups of 20 larvae, ranging from 200 to $300 \mathrm{mg}$ in weight and with no signs of melanization, were randomly chosen and used for subsequent infection. A $10 \mu \mathrm{l}$ Hamilton syringe was used to inject $5 \mu \mathrm{l}$ aliquots of bacterial inoculum $\left(5 \times 10^{5}\right.$ c.f.u. $\left.\mathrm{ml}^{-1}\right)$ into the haemocoel of each larva via the last left proleg. Bacterial colony counts on BHI plates were used to confirm the initial inoculum. Groups injected with saline solution or heat-inactivated $(20 \mathrm{~min}$ at $75{ }^{\circ} \mathrm{C}$ ) cells were used as controls in each experiment. After injection, larvae were incubated at $37^{\circ} \mathrm{C}$, and survival was recorded at selected intervals. Larvae were scored as dead when they displayed no movement in response to touch. Kaplan-Meier killing curves were plotted and estimation of differences in survival were compared by using the log-rank test. A $P$-value $\leqslant 0.001$ was considered significant. All data were analysed with GraphPad Prism 4.0 software. Experiments were performed independently three times with similar results.

\section{RESULTS AND DISCUSSION}

\section{In silico analysis of $E$. faecalis $c / p B$}

Analysis of the E. faecalis V583 genome sequence (Paulsen et al., 2003) identified the gene encoding the ClpB ATPase. The $c l p B$ gene encodes a protein of 868 aa with a predicted molecular mass of approximately $98 \mathrm{kDa}$ and an estimated pI of 4.78. The protein presents two conserved nucleotidebinding domains (NBD) separated by a relatively long spacer (154 aa). The NBDs present the consensus sequences Walker-A and Walker-B (Fig. 1a). Analysis of the amino acid sequence confirmed the presence of the N-terminal region and the two $\mathrm{C}$-terminal signature sequences characteristic of $\mathrm{ClpB}$ (Fig. 1b). The predicted start codon is preceded by a putative $\sigma^{\mathrm{A}}$-type promoter (TTGACC$\mathrm{N}_{17}$-TATAAT) (Fig. 2), and a putative transcription terminator $\left[\Delta G=-45.3 \mathrm{kcal} \mathrm{mol}^{-1}\left(189.5 \mathrm{~kJ} \mathrm{~mol}^{-1}\right)\right]$ was identified downstream of the predicted stop codon. In addition, a CtsR-binding sequence (GGTCAAA- ${ }_{3}$-GGTCAAT) was identified starting $30 \mathrm{bp}$ upstream of the -10 sequence. A putative ribosome-binding site (GGGAGG) was found
8 bp upstream of the ATG start codon. Of note, sequence analysis identified a second initiation codon (GTG) and a putative ribosome-binding site (AGGAGG) downstream of the ATG start codon (Fig. 2). This potential internal translation initiation site suggests that a smaller form of $\mathrm{ClpB}$, with a theoretical molecular mass of approximately $80 \mathrm{kDa}$, may be produced. Of note, sequence analysis of the $c l p B$ gene from several other E. faecalis strains with complete genomes available at the Broad Institute (http:// www.broadinstitute.org/annotation/genome/enterococcus_ faecalis/MultiHome.html) indicated that the second putative translational initiation region inside $\operatorname{clp} B$ is fully conserved in other E. faecalis strains.

\section{Induction of $c / p B$ mRNA and ClpB in response to heat shock}

To determine whether $\mathrm{ClpB}$ expression is modulated by heat stress, Northern blot, ${ }^{35} \mathrm{~S}$-pulse protein labelling and Western blot analyses were performed. Northern analysis revealed a single stress-inducible transcript of $2.6 \mathrm{~kb}$, compatible with a $c l p B$ monocistronic transcript (Fig. $3 a)$. No induction was observed when the temperature was shifted from 37 to up to $45{ }^{\circ} \mathrm{C}$. However, at 48 and $50{ }^{\circ} \mathrm{C}$, a significant increase in induction of 10 - and 35-fold, respectively, was observed (Fig. 3a). The result of the autoradiogram of ${ }^{35} \mathrm{~S}$-labelled cells and Western blotting further confirmed $\mathrm{ClpB}$ as a heat-shock protein. Autoradiograms of polypeptides labelled at temperatures ranging from 37 to $55{ }^{\circ} \mathrm{C}$ revealed two heat-inducible bands of approximately 95 and $80 \mathrm{kDa}$ (Fig. 3b), as well as the induction of the molecular chaperones DnaK and GroEL that have been identified previously (Laport et al., 2001). All heat-inducible bands reached a maximum induction at temperatures between 48 and $50{ }^{\circ} \mathrm{C}$. Western blotting using a polyclonal antibody against ClpB identified two bands of approximately 95 and $80 \mathrm{kDa}$, suggesting that $\mathrm{ClpB}$ may be present in two isoforms (Fig. 3c). The predicted molecular mass of ClpB is $98 \mathrm{kDa}$, whereas in silico analysis suggested the presence of a putative internal translational initiation site that could potentially yield a smaller $80 \mathrm{kDa}$ protein. Although we cannot rule out that the smaller band is a result of enzymic cleavage of the $98 \mathrm{kDa} \mathrm{ClpB}$, it is tempting to speculate that the $80 \mathrm{kDa}$ protein is a product from a second and internal translational initiation site. Of note, similar observations have been reported in Escherichia coli and in the unicellular cyanobacterium Synechococcus sp., in which $c_{l p B}$ was shown to contain two initiation sites for translation, resulting in the synthesis of $\mathrm{ClpB}$ polypeptides of $\sim 95$ and $\sim 80 \mathrm{kDa}$ (Park et al., 1993; Clarke \& Eriksson, 2000). Interestingly, in the cyanobacterium Synechococcus sp., the smaller $\mathrm{ClpB}$ displayed the same capacity as the larger $\mathrm{ClpB}$ for the acquisition of thermotolerance (Eriksson \& Clarke, 2000). Moreover, a potential internal translation initiation site preceded by a typical ribosome binding site has also been identified in L. monocytogenes (Chastanet et al., 2004), suggesting that the existence of 
(a)

MNIEKMTTTLQEAIAEAQKVAVTROHQEIDIAHLWKIFLQPNHFGRNFYTDAGLDVDAFE 60

KFT-----ALA-A--LA----H-H-----------PHHLA-ALH N-Terminal

REVDNALDEYPSVAGGNVQYGQNLSQNLFHLLOEADSLREEEODEFLSTEIVLLALMKLK 120

PIIGRDEEIRDVIRILSRKTKNNPVLIGEPGVGKTAIVEGLAQRIVRKDVPENLKDKTIF 180

ATP-1 WalkerA G----GKT

PIIGRDEEIRDVIRILSRKTKNNPVLIGEPGVGKTAIVEGLAQRIVRKDVPENLKDKTIF 240 SLDMGALIAGAKFRGEFEERLKAVLKEVKKSDGKIILFIDEIHNIVGAGKTEGSMDAGNL 300 LKPMLARGELHLIGATTLDEYRQYMEKDKALERREQKVLVKEPTVEDTISILRGLKERFE 360

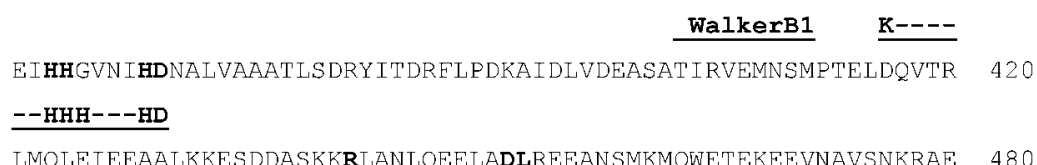

\section{WalkerB2 R-------AIDLHD}

IDKAKHELEDAENNYDLERAAVLRHGTIPQLEHELKELEEKNAKDNVKMVQESVTENEIA 540 Middle II R-GDLAR-SELQYG-IP

QVVGRLTGI PVTKLVEGEREKLMKLNETLHKRVIGQDEAVDAVSDAVIRSRAGLQDPNRP 600

RWTGIPV-KH Middle III

LGS FLF LGPTGVGRTELAKALAEDLFDSEDHMVRIDMSEYMEKHAVSRLVGAPPGYVGYE 660 G----GKT ATP-2 WalkerA

EGGQLTEAVRRNPYTIVLLDEIEKAHPDVFNILLQVLDDGRLTDSKGRVVDFKNTVLIMT 720 WalkerB R------------HHHHD

SNIGSQLLLEGVTPEGT I PEEVENQVMN ILKGHFKPEFLNRIDDTILFTPLSLDNVKGII 780 C-Terminal IV ERPEFLNRLDEIIVFL

GKMTAQLAHRLEQQEIVLEITDEAKTWIAENGYEPAYGARPLKREITREVETPLAKEIVS 840 C-Terminal V GARPLRR

GRVMPKTKVTISLLDNQLVEENEPIEEV

(b)

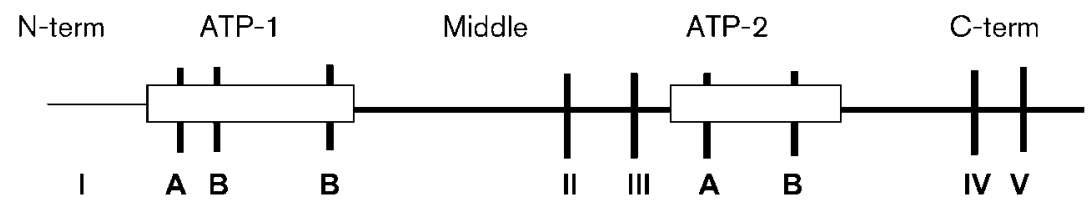

Fig. 1. Structural features of the ClpB proteins of $E$. faecalis. (a) Amino acid sequence deduced from the $E$. faecalis $c / p B$ gene indicating the consensus sequences. (b) Consensus motifs of the ClpB proteins. ATP-1 and ATP-2 represent the Walker-type nucleotide-binding sites: Walker-A is a glycine-containing segment and Walker-B represents hydrophobic segment motifs. I, N-terminal; II and III, middle; and IV and $\mathrm{V}, \mathrm{C}$-terminal consensus sequences.

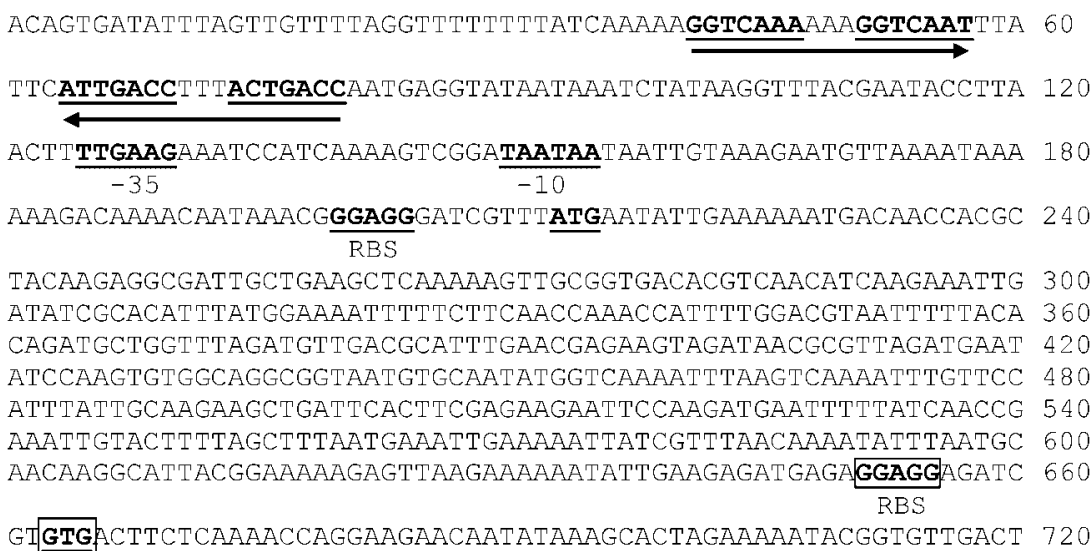

Fig. 2. Nucleotide sequence of the promoter region and the $5^{\prime}$ coding region of the $E$. faecalis $c / p B$ gene. Regulatory sequences, in bold type and underlined, are as follows: one putative CtsR element (consensus sequence GGTCAAANANGGTCAAA) indicated with an arrow below, the putative -35 and -10 regions, the initiation codon ATG and its ribosome-binding site (RBS), and a second putative initiation codon GTG and its related RBS (boxed). 
two different-sized polypeptides may be a common feature of ClpB proteins. Finally, Western blot analysis with the $\Delta c l p B$ strain confirmed that the $98 \mathrm{kDa}$ polypeptide was $\mathrm{ClpB}$. The $80 \mathrm{kDa}$ band was still observed in the $\Delta c l p B$ strain albeit not as strongly as it was detected in the parent strain (Fig. 3d). Initially, this finding indicates that the
$80 \mathrm{kDa}$ band is not the predicted $\mathrm{ClpB}$ internal product but another heat-inducible protein that cross-reacts with the ClpB antibody. However, given the precedents from the $\mathrm{ClpB}$ literature and our own findings, we believe that $\mathrm{ClpB}$ is in fact produced in two different isoforms and that another protein, which co-migrates with the smaller

(a)

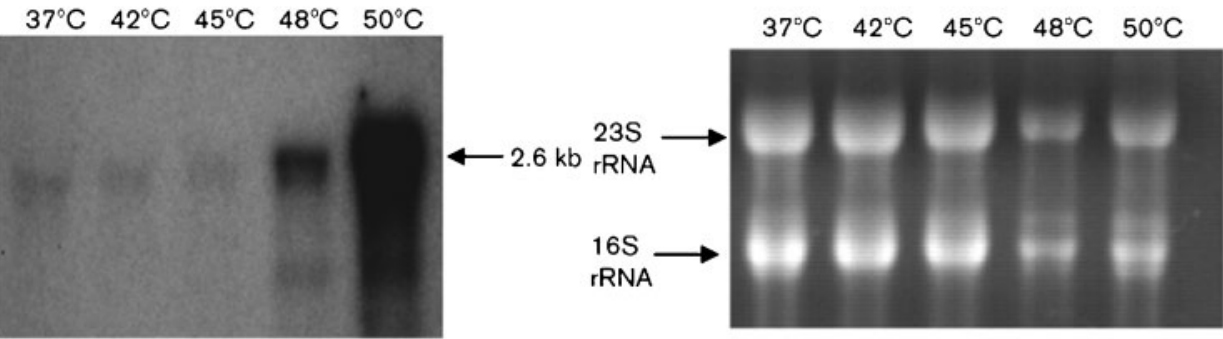

(b)

$37^{\circ} \mathrm{C} \quad 42^{\circ} \mathrm{C} \quad 45^{\circ} \mathrm{C} \quad 48^{\circ} \mathrm{C} \quad 50^{\circ} \mathrm{C} \quad 52^{\circ} \mathrm{C} \quad 55^{\circ} \mathrm{C}$
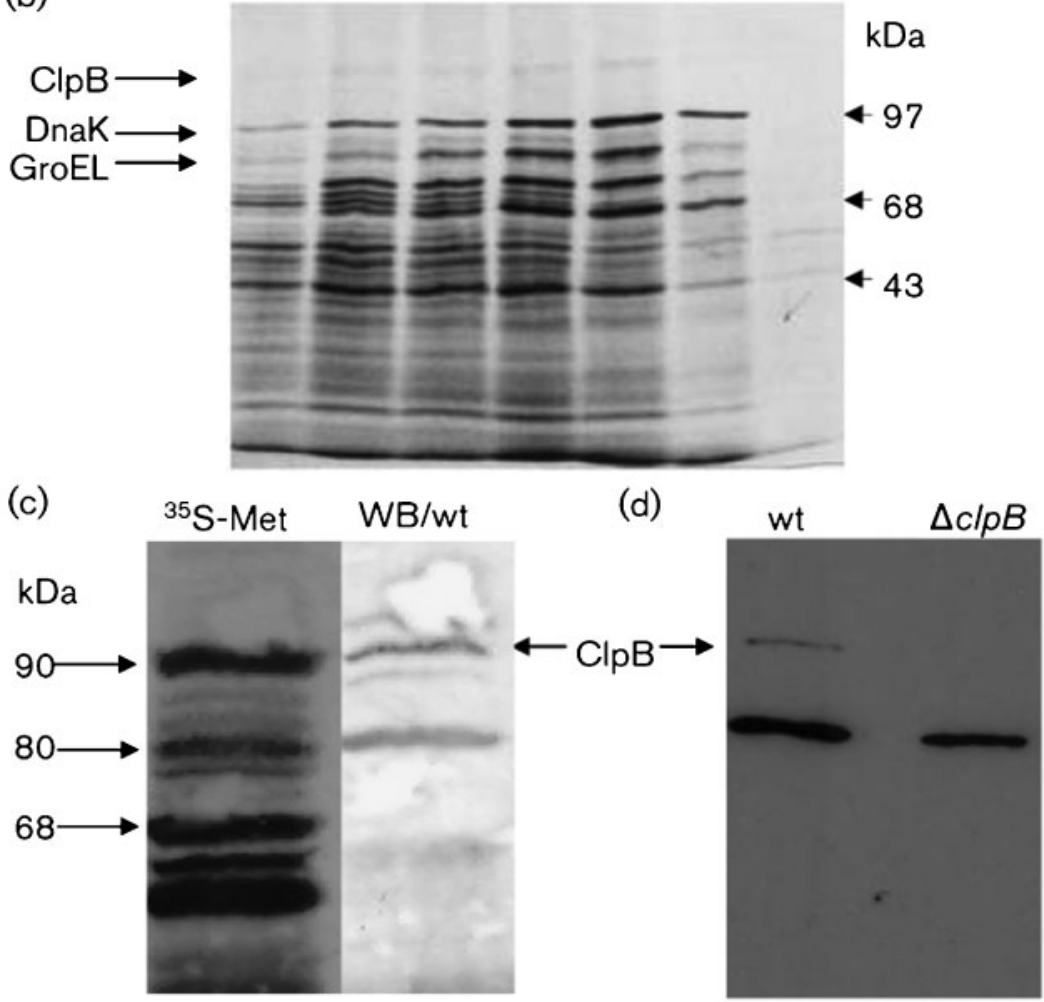

Fig. 3. Induction of $c / p B m R N A$ and $C l p B$ in response to heat shock. (a) Northern blot analysis of the E. faecalis $c / p B$ gene. In order to stimulate the production of the heat-shock mRNA, the cells were either cultivated at $37{ }^{\circ} \mathrm{C}$ (control cells) or stressed by upshift to $42,45,48$ or $50{ }^{\circ} \mathrm{C}$ for $10 \mathrm{~min}$. Total RNA was separated under denaturing conditions, transferred to a nitrocellulose membrane, and hybridized to a $c / p B$-specific probe (left). A parallel gel was stained with ethidium bromide to show equal loading of the slots (right). (b) Influence of supra-optimum temperatures on protein synthesis. Wild-type cells were either incubated at $37{ }^{\circ} \mathrm{C}$ (control) or treated at $42,45,48,50,52$ or $55{ }^{\circ} \mathrm{C}$ in the presence of $\left[{ }^{35}\right.$ S]methionine. Labelled proteins were separated by SDS-PAGE and analysed by autoradiography. The ClpB protein is indicated. DnaK and GroEL, which were previously identified, are also indicated (Laport et al., 2001). (c) Identification of the ClpB protein. Wild-type (wt) cells were subjected to heat shock at $45{ }^{\circ} \mathrm{C}$ in the presence of $\left[{ }^{35} \mathrm{~S}\right]$ methionine. Labelled proteins were separated by SDSPAGE and analysed by either autoradiogram $\left({ }^{35} \mathrm{~S}-\mathrm{Met}\right)$ or Western blotting using polyclonal antibodies raised against Synechococcus spp. ClpB diluted $1: 1000$. (d) Western blotting of wild-type (wt) or $\Delta c / p B$ cells subjected to heat shock at $45{ }^{\circ} \mathrm{C}$ showing the cross-reaction of the ClpB polyclonal antibody. 
$\mathrm{ClpB}$, cross-reacted with the $\mathrm{ClpB}$ antibody. Considering that Clp ATPases are relatively conserved, it is possible that the cross-reacting protein is one of the two other large class $1 \mathrm{Clp}$ ATPases, ClpC and ClpE, encoded in the E. faecalis genome. Of note, $\mathrm{ClpC}$ has a predicted molecular mass of $92 \mathrm{kDa}$ and shares $61 \%$ identity with the E. faecalis $\mathrm{ClpB}$, whereas $\mathrm{ClpE}$ has a predicted molecular mass of $82.9 \mathrm{kDa}$ and shares $55 \%$ identity with $\mathrm{ClpB}$. Work is underway to identify the $80 \mathrm{kDa}$ heatinducible protein(s).

\section{clpB is a member of the CtsR regulon}

Due to the identification of a CtsR consensus-binding motif in the promoter region of the $\operatorname{clp} B$ gene, a $\Delta c t s R$ strain was constructed to investigate the role of CtsR in controlling $c l p B$ expression. qRT-PCR analysis revealed that, under non-stressful conditions, CtsR is indeed responsible for $c l p B$ repression since an approximate 2$\log$ increase in $\operatorname{clp} B$ expression was observed in the $\Delta c t s R$ strain compared with the wild-type strain (Table 3). Expression of the transcript of the housekeeping gene $16 \mathrm{~S}$ rDNA was used as an internal standard and no difference was observed between samples (data not shown). Interestingly, induction after exposure to $48{ }^{\circ} \mathrm{C}$ was also observed in the $\Delta c t s R$ strain, suggesting that the $\operatorname{clp} B$ gene may have an additional layer of regulation. In Grampositive bacteria, HrcA and CtsR are two major transcriptional repressors that regulate expression of distinct heat-shock genes (Narberhaus, 1999). The HrcA repressor recognizes a DNA element called CIRCE (for controlling inverted repeat of chaperone expression) and is mainly involved in the transcriptional regulation of the $g r o E$ and dnaK operons. In some cases, however, heat-shock genes are under dual negative control by the HrcA and CtsR repressors. This is the case for the $d n a K$ operon in Staphylococcus aureus, clpP in Streptococcus salivarius and the groE operon in several streptococci (Chastanet et al., 2001, 2003; Lemos \& Burne, 2002; Chastanet \& Msadek, 2003). Sequence analysis of the promoter regions of the $c l p B$ gene did not indicate the presence of a CIRCE element, indicating that HrcA does not play a role in the regulation of $c l p B$ in E. faecalis.

\section{Growth characteristics, stress tolerance of and biofilm formation by the $\Delta c / p B$ strain}

Analysis of the growth rates and doubling time of the $\Delta c l p B$ strain under normal growth conditions (i.e. aerobic conditions at $37{ }^{\circ} \mathrm{C}$ ) indicated that the mutant grew slightly slower than the parent strain (Table $3 ; P \leqslant 0.05$ ). The capacity of the $\triangle c l p B$ strain to grow under a variety of stress conditions was also examined. No significant differences in growth between the mutant and parent strains were observed when cells were grown at different temperatures ( 45 and $48{ }^{\circ} \mathrm{C}$ ), at $\mathrm{pH} 5$ or in the presence of $\mathrm{NaCl}$ or $\mathrm{H}_{2} \mathrm{O}_{2}$. However, the slower growth of $\Delta c l p B$ at pH 9 compared with its parent was statistically significant
(Table 4; $P \leqslant 0.05$ ). We also tested the susceptibility of the mutant strain to $\mathrm{HCl}, \mathrm{H}_{2} \mathrm{O}_{2}$ and $\mathrm{NaOCl}$ using disc diffusion assays. Based on the diameter of the zone of inhibition for each compound tested, no significant differences were observed between strains. Finally, the capacity of the mutant to form biofilms on polystyrene microtitre plates was also assessed. Quantitative analysis of biofilms formed by the $\Delta c l p B$ mutant did not differ from biofilms formed by the parent OG1RF strain (data not shown).

\section{ClpB contributes to thermotolerance}

While expression of E. faecalis $\operatorname{clp} B$ was highly induced upon heat shock, the $\Delta c l p B$ strain did not show any inherent growth defect at elevated temperatures. Here, we tested whether $\mathrm{ClpB}$ is necessary for the acquisition of thermotolerance in E. faecalis (Fig. 4). In the wild-type strain, pre-incubation of the cells at $50{ }^{\circ} \mathrm{C}$ for $30 \mathrm{~min}$ prior to exposure to a lethal temperature $\left(60{ }^{\circ} \mathrm{C}\right)$ resulted in full protection for up to $60 \mathrm{~min}$ (Fig. 4). In contrast with the

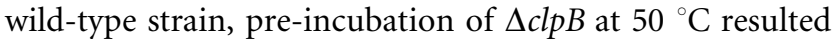
in only an intermediate level of protection against lethal $60{ }^{\circ} \mathrm{C}$ treatment. The introduction of pTG55 (clpB plasmid) partially restored thermotolerance in $\Delta c l p B$ (c $\Delta c l p B$ strain). Notably, after $60 \mathrm{~min}$ at $60{ }^{\circ} \mathrm{C}$, the cells grown in the presence of nisin (induced) showed an approximately 15 -fold increased heat tolerance compared with the $\Delta c l p B$ strain, whereas $c \Delta c l p B$ grown in the absence of nisin displayed fivefold increased survival (Fig. 4). This result showed that $\mathrm{ClpB}$ plays an important role in the induction of thermotolerance and this fact might contribute to the persistence of $E$. faecalis in different environments. Notably, $\mathrm{ClpB}$ has been implicated in the acquisition of thermotolerance in Escherichia coli and in other Gram-positive pathogens, such as L. monocytogenes and Staphylococcus aureus (Thomas \& Baneyx, 1998; Chastanet et al., 2004; Frees et al., 2004). In Escherichia coli, the $\mathrm{ClpB}$ requirement for induction of thermotolerance is

Table 3. $q R T-P C R-b a s e d$ expression profiles of $c / p B$

Total RNA was isolated from mid-exponential phase cultures that were kept at $37{ }^{\circ} \mathrm{C}$ (control) or incubated at $48{ }^{\circ} \mathrm{C}$ for $30 \mathrm{~min}$. The results were obtained using qRT-PCR as described in Methods. Data are means \pm SD of three independent experiments performed with RNA isolated from three independent cultures. All samples were assayed in triplicate. ND, Not done.

\begin{tabular}{|lc|}
\hline Strain & Relative $\boldsymbol{c l} \boldsymbol{p B}$ mRNA (copies $\left.\boldsymbol{\mu l}^{-\mathbf{1}}\right)$ \\
\hline OG1RF $\left(37^{\circ} \mathrm{C}\right)$ & $8.53 \times 10^{4} \pm 1.33 \times 10^{4}$ \\
OG1RF $\left(48^{\circ} \mathrm{C}\right)$ & $1.14 \times 10^{6} \pm 4.41 \times 10^{5 *}$ \\
$\Delta c t s R\left(37^{\circ} \mathrm{C}\right)$ & $4.37 \times 10^{6} \pm 1.99 \times 10^{6}$ \\
$\Delta c t s R\left(48^{\circ} \mathrm{C}\right)$ & $1.00 \times 10^{7} \pm \mathrm{ND}^{*}$ \\
\hline
\end{tabular}

${ }^{\star}$ Significant difference compared with the control $(P \leqslant 0.05)$. 
Table 4. Growth characteristics of the OG1RF and $\Delta c / p B$ strains grown under different conditions

Doubling time data are means $\underline{ \pm S D}$ of three independent experiments.

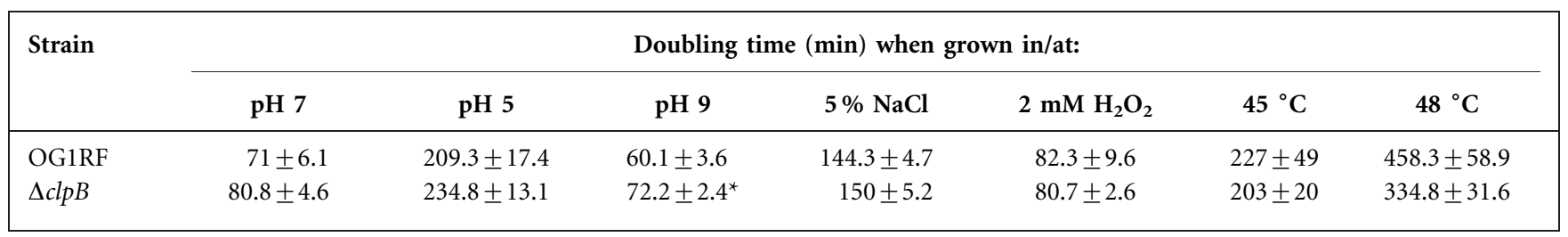

${ }^{*}$ Significant difference compared with OG1RF $(P \leqslant 0.05)$.

related to its ability to act as a molecular chaperone rescuing protein aggregates formed during heat-shock treatment (Thomas \& Baneyx, 1998; Doyle et al., 2007). This aggregation-reversing activity of $\mathrm{ClpB}$ requires cooperation with the DnaK chaperone machinery (Doyle et al., 2007) but evidence of ClpB-DnaK interactions in Gram-positive bacteria are yet to be demonstrated.

\section{Virulence of the $\Delta c / p B$ strain is attenuated in the G. mellonella model}

Killing of the larvae of G. mellonella has been routinely used as a virulence model for several pathogenic bacteria, including E. faecalis (Park et al., 2007; Lebreton et al., 2009). Therefore, G. mellonella was tested as a model to verify whether $E$. faecalis $\mathrm{ClpB}$ is involved in virulence. As shown in Fig. 5, the rates of killing were significantly lower in larvae infected with $\Delta c l p B$ than in those infected with the wild-type strain $(P \leqslant 0.001)$. To confirm that killing was due to an infectious process, we also assessed the survival of larvae injected with heat-killed E. faecalis or saline with minimal killing observed within the two groups during the course of the experiment. Of note, the $\mathrm{ClpB}$ protein has

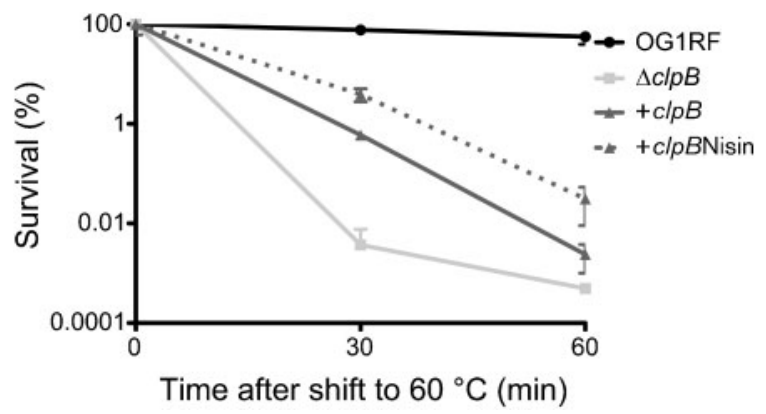

Fig. 4. $\mathrm{ClpB}$ is important for development of thermotolerance. Cultures of wild-type OG1RF, $\Delta c / p B$, the complemented $c \Delta c / p B$ and nisin-induced $c \Delta c / p B$ strains were grown exponentially at $37{ }^{\circ} \mathrm{C}$ to $\mathrm{OD}_{600} \sim 0.4$. At this point, cultures were pre-incubated at $50{ }^{\circ} \mathrm{C}$ for $30 \mathrm{~min}$ prior to exposure to $60{ }^{\circ} \mathrm{C}$ (a lethal temperature) for 30 and $60 \mathrm{~min}$. Cell survival was evaluated by plating diluted samples on $\mathrm{BHI}$ plates. The result presented is a representative of five independent experiments; error bars, SD. been implicated in the expression of virulence by other Gram-positive pathogens. In Staphylococcus aureus and P. gingivalis, ClpB was associated with intracellular survival and multiplication (Frees et al., 2004; Capestany et al., 2008), and virulence of $L$. monocytogenes and $P$. gingivalis lacking $c l p B$ was significantly attenuated in murine models of infection (Chastanet et al., 2004; Yuan et al., 2007).

In G. mellonella, the production of superoxide and other reactive oxygen species (ROS) via a respiratory burst by the insect specialized phagocytic cells, known as haemocytes, is an important line of defence against microbial infections (Bergin et al., 2005). Thus, we hypothesized that the reduced virulence of the $\Delta c l p B$ strain in G. mellonella could be due to increased sensitivity to ROS. To verify this possibility, we tested the ability of the wild-type and mutant strains to survive a lethal treatment with $\mathrm{H}_{2} \mathrm{O}_{2}$. Our results indicated that both strains exhibited similar sensitivity to $\mathrm{H}_{2} \mathrm{O}_{2}$ killing (data not shown), suggesting

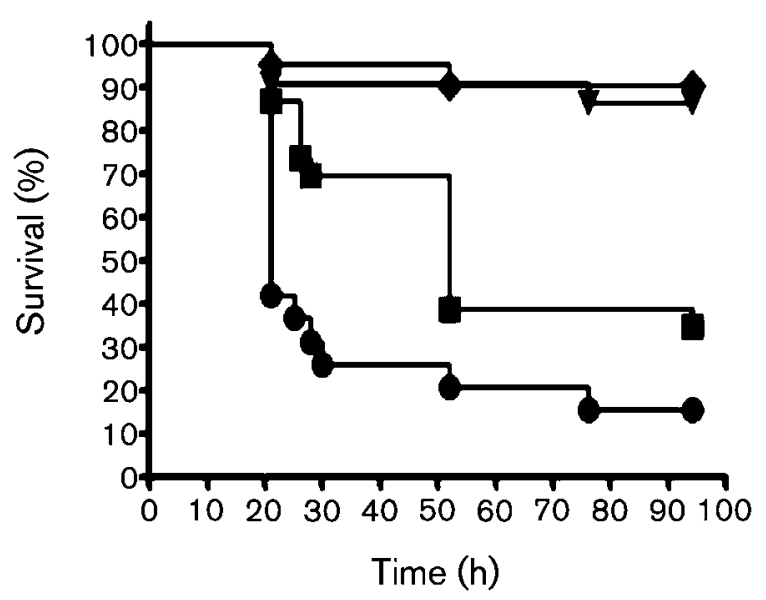

Fig. 5. Killing of $G$. mellonella larvae infected with $E$. faecalis OG1RF and $\Delta c / p B$ at $37{ }^{\circ} \mathrm{C}$. Survival (Kaplan-Meyer) plots of larvae injected with OG1RF $(\boldsymbol{O})$ and $\Delta c / p B(\boldsymbol{\square})$ strains. Larvae injected with saline solution $(\boldsymbol{\nabla})$ or heat-killed OG1RF $(\boldsymbol{\Delta})$ were used as controls with minimum killing. The experiments were repeated three times, and the results are representative of a typical experiment. Compared with the wild-type OG1RF strain, $\Delta c / p B$ showed attenuated virulence $(P \leqslant 0.001)$. 
that other host-derived factors may be responsible for the attenuated virulence of $\Delta c l p B$ in this particular model.

In conclusion, we report the identification and characterization of the $\mathrm{ClpB}$ ATPase. We demonstrate that $\mathrm{ClpB}$ is a member of the CtsR regulon and, even though it is induced by heat stress, it is not required for growth at high temperatures. However, expression of $\mathrm{ClpB}$ appears to play a major role in induced thermotolerance and in pathogenesis, as assessed using the G. mellonella virulence model. Future efforts will be devoted to the identification of proteins that interact with $\mathrm{ClpB}$, which will help to disclose the underlying mechanisms by which $\mathrm{ClpB}$ affects virulence traits in E. faecalis.

\section{ACKNOWLEDGEMENTS}

The authors express their thanks to Dr Celia A. Soares, for encouragement, and to Dr Adrian K. Clarke, for providing antiClpB. This study was supported by Brazilian grants [Conselho Nacional de Desenvolvimento Científico e Tecnológico (CNPq), Fundação Carlos Chagas Filho de Amparo à Pesquisa do Estado do Rio de Janeiro (FAPERJ) and Pronex/FAPERJ] to M.G.-deM. N.E.M.O. was a recipient of a scholarship from Coordenação de Aperfeiçoamento de Pessoal de Nível Superior Brazil and a Travel scholarship from CNPq.

\section{REFERENCES}

Abranches, J., Candella, M. M., Wen, Z. T., Baker, H. V. \& Burne, R. A. (2006). Different roles of EIIAB ${ }^{\mathrm{Man}}$ and EII ${ }^{\mathrm{Glc}}$ in regulation of energy metabolism, biofilm development, and competence in Streptococcus mutans. J Bacteriol 188, 3748-3756.

Ahn, S. J., Lemos, J. A. \& Burne, R. A. (2005). Role of HtrA in growth and competence of Streptococcus mutans UA159. J Bacteriol 187, 3028-3038.

Bergin, D., Reeves, E. P., Renwick, J., Wientjes, F. B. \& Kavanagh, K. (2005). Superoxide production in Galleria mellonella hemocytes: identification of proteins homologous to the NADPH oxidase complex of human neutrophils. Infect Immun 73, 4161-4170.

Bryan, E. M., Bae, T., Kleerebezem, M. \& Dunny, G. M. (2000). Improved vectors for nisin-controlled expression in Gram-positive bacteria. Plasmid 44, 183-190.

Capestany, C. A., Tribble, G. D., Maeda, K., Demuth, D. R. \& Lamont, R. J. (2008). Role of the Clp system in stress tolerance, biofilm formation, and intracellular invasion in Porphyromonas gingivalis. J Bacteriol 190, 1436-1446.

Chastanet, A. \& Msadek, T. (2003). clpP of Streptococcus salivarius is a novel member of the dually regulated class of stress response genes in Gram-positive bacteria. J Bacteriol 185, 683-687.

Chastanet, A., Prudhomme, M., Claverys, J. P. \& Msadek, T. (2001). Regulation of Streptococcus pneumoniae clp genes and their role in competence development and stress survival. J Bacteriol 183, 72957307.

Chastanet, A., Fert, J. \& Msadek, T. (2003). Comparative genomics reveal novel heat shock regulatory mechanisms in Staphylococcus aureus and other Gram-positive bacteria. Mol Microbiol 47, 1061-1073.

Chastanet, A., Derre, I., Nair, S. \& Msadek, T. (2004). $c l p B$, a novel member of the Listeria monocytogenes CtsR regulon, is involved in virulence but not in general stress tolerance. J Bacteriol 186, 11651174.
Clarke, A. K. \& Eriksson, M. J. (2000). The truncated form of the bacterial heat shock protein ClpB/HSP100 contributes to development of thermotolerance in the cyanobacterium Synechococcus sp. strain PCC 7942. J Bacteriol 182, 7092-7096.

Derré, I., Rapoport, G. \& Msadek, T. (1999). CtsR, a novel regulator of stress and heat shock response, controls $c l p$ and molecular chaperone gene expression in Gram-positive bacteria. Mol Microbiol 31, 117131.

Doyle, S. M., Hoskins, J. R. \& Wickner, S. (2007). Collaboration between the ClpB AAA + remodeling protein and the DnaK chaperone system. Proc Natl Acad Sci U S A 104, 11138-11144.

Eriksson, M. J. \& Clarke, A. K. (1996). The heat shock protein ClpB mediates the development of thermotolerance in the cyanobacterium Synechococcus sp. strain PCC 7942. J Bacteriol 178, 4839-4846.

Eriksson, M. J. \& Clarke, A. K. (2000). The Escherichia coli heat shock protein $\mathrm{ClpB}$ restores acquired thermotolerance to a cyanobacterial clpB deletion mutant. Cell Stress Chaperones 5, 255-264.

Fisher, K. \& Phillips, C. (2009). In vitro inhibition of vancomycinsusceptible and vancomycin-resistant Enterococcus faecium and E. faecalis in the presence of citrus essential oils. Br J Biomed Sci 66, 180185.

Flahaut, S., Benachour, A., Giard, J. C., Boutibonnes, P. \& Auffray, Y. (1996a). Defense against lethal treatments and protein synthesis induced by $\mathrm{NaCl}$ in Enterococcus faecalis ATCC 19433. Arch Microbiol 165, 317-324.

Flahaut, S., Hartke, A., Giard, J. C., Benachour, A., Boutibonnes, P. \& Auffray, Y. (1996b). Relationship between stress response toward bile salts, acid and heat treatment in Enterococcus faecalis. FEMS Microbiol Lett 138, 49-54.

Flahaut, S., Hartke, A., Giard, J. C. \& Auffray, Y. (1997). Alkaline stress response in Enterococcus faecalis: adaptation, cross-protection, and changes in protein synthesis. Appl Environ Microbiol 63, 812-814.

Frees, D., Chastanet, A., Qazi, S., Sorensen, K., Hill, P., Msadek, T. \& Ingmer, H. (2004). Clp ATPases are required for stress tolerance, intracellular replication and biofilm formation in Staphylococcus aureus. Mol Microbiol 54, 1445-1462.

Giard, J. C., Hartke, A., Flahaut, S., Benachour, A., Boutibonnes, P. \& Auffray, Y. (1997). Glucose starvation response in Enterococcus faecalis JH2-2, survival and proteins analysis. Res Microbiol 148, 27-35.

Giard, J. C., Rince, A., Capiaux, H., Auffray, Y. \& Hartke, A. (2000). Inactivation of the stress- and starvation-inducible gls24 operon has a pleiotropic effect on cell morphology, stress sensitivity and gene expression in Enterococcus faecalis. J Bacteriol 182, 4512-4520.

Grant, S. G., Jessee, J., Bloom, F. R. \& Hanahan, D. (1990). Differential plasmid rescue from transgenic mouse DNAs into Escherichia coli methylation-restriction mutants. Proc Natl Acad Sci U S A 87, 4645-4649.

Hartke, A., Giard, J. C., Laplace, J. M. \& Auffray, Y. (1998). Survival of Enterococcus faecalis in an oligotrophic microcosm: changes in morphology, development of general stress resistance, and analysis of protein synthesis. Appl Environ Microbiol 64, 4238-4245.

Houry, W. A. (2001). Chaperone-assisted protein folding in the cell cytoplasm. Curr Protein Pept Sci 2, 227-244.

Kristich, C. J., Chandler, J. R. \& Dunny, G. M. (2007). Development of a host-genotype-independent counterselectable marker and highfrequency conjugative delivery system and their use in genetic analysis of Enterococcus faecalis. Plasmid 57, 131-144.

Laport, M. S., Castro, A. C., Villardo, A., Lemos, J. A., Bastos, M. C. F. \& Giambiagi-deMarval, M. (2001). Expression of the major heat shock proteins DnaK and GroEL in Streptococcus pyogenes: a comparison to Enterococcus faecalis and Staphylococcus aureus. Curr Microbiol 42, 264-268. 
Laport, M. S., Lemos, J. A., Bastos, M. C. F., Burne, R. A. \& Giambiagi-deMarval, M. (2004). Transcriptional analysis of the groE and dnaK heat-shock operons of Enterococcus faecalis. Res Microbiol 155, 252-258.

Laport, M. S., Santos, L. L., Lemos, J. A. C., Bastos, M. C. F., Burne, R. A. \& Giambiagi-deMarval, M. (2006). Organization of the heatshock dnaK and groE operons of the nosocomial pathogen Enterococcus faecium. Res Microbiol 157, 162-168.

Lebreton, F., Riboulet-Bisson, E., Serror, P., Sanguinetti, M., Posteraro, B., Torelli, R., Hartke, A., Auffray, Y. \& Giard, J.-C. (2009). ace, which encodes an adhesin in Enterococcus faecalis, is regulated by Ers and is involved in virulence. Infect Immun 77, 2832-2839.

Leenhouts, K., Buist, G., Bolhuis, A., ten Berge, A., Kiel, J., Mierau, I., Dabrowska, M., Venema, G. \& Kok, J. (1996). A general system for generating unlabelled gene replacements in bacterial chromosomes. Mol Gen Genet 253, 217-224.

Lemos, J. A. C. \& Burne, R. A. (2002). Regulation and physiological significance of ClpC and ClpP in Streptococcus mutans. J Bacteriol 184, 6357-6366.

Loo, C. Y., Corliss, D. A. \& Ganeshkumar, N. (2000). Streptococcus gordonii biofilm formation: identification of genes that code for biofilm phenotypes. J Bacteriol 182, 1374-1382.

Murray, B. E. (1990). The life and times of the Enterococcus. Clin Microbiol Rev 3, 46-65.

Narberhaus, F. (1999). Negative regulation of bacterial heat shock genes. Mol Microbiol 31, 1-8.

Park, S. K., Kim, K. I., Woo, K. M., Seol, J. H., Tanaka, K., Ichihara, A., Ha, D. B. \& Chung, C. H. (1993). Site-directed mutagenesis of the dual translational initiation sites of the $\operatorname{clp} B$ gene of Escherichia coli and characterization of its gene products. J Biol Chem 268, 20170-20174.

Park, S. Y., Kim, K. M., Lee, J. H., Seo, S. J. \& Lee, I. H. (2007). Extracellular gelatinase of Enterococcus faecalis destroys a defense system in insect hemolymph and human serum. Infect Immun 75, 1861-1869.

Paulsen, I. T., Banerjei, L., Myers, G. S., Nelson, K. E., Seshadri, R., Read, T. D., Fouts, D. E., Eisen, J. A., Gill, S. R. \& other authors (2003). Role of mobile DNA in the evolution of vancomycin-resistant Enterococcus faecalis. Science 299, 2071-2074.

Sambrook, J. \& Russell, D. W. (2001). Molecular Cloning: a Laboratory Manual, 3rd edn. Cold Spring Harbor, NY: Cold Spring Harbor Laboratory.

Schirmer, E. C., Glover, J. R., Singer, M. A. \& Lindquist, S. (1996). HSP100/Clp proteins: a common mechanism explains diverse functions. Trends Biochem Sci 21, 289-296.

Thomas, J. G. \& Baneyx, F. (1998). Roles of the Escherichia coli small heat shock proteins $i b p A$ and $i b p B$ in thermal stress management: comparison with ClpA, ClpB and HtpG in vivo. J Bacteriol 180, 51655172 .

Wawrzynow, A., Banecki, B. \& Zylicz, M. (1996). The Clp ATPases define a novel class of molecular chaperones. Mol Microbiol 21, 895899.

Yuan, L., Rodrigues, P. H., Belanger, M., Dunn, J. R. W. \& Progulske-Fox, A. (2007). The Porphyromonas gingivalis $c l p B$ gene is involved in cellular invasion in vitro and virulence in vivo. FEMS Immunol Med Microbiol 51, 388-398.

Edited by: K. E. Weaver 